\title{
PEMANFAATAN KAIN TENUN ETNIK SASAK, SAMAWA DAN MBOJO SEBAGAI PERWUJUDAN EKONOMI KREATIF
}

\author{
Peri Anggraini ${ }^{1 *}$, RizkiAmalia Nuraini ${ }^{1)}$, Vivin Wulantari ${ }^{1)}$, Ulia Arta Sari ${ }^{1)}$, Ririn Ayu \\ Prastika $^{2)}$ \\ ${ }^{1)}$ Program Studi Pendidikan Guru Sekolah Dasar, Universitas Mataram \\ ${ }^{2)}$ Program Studi Sosiologi, Universitas Mataram \\ Jl. Majapahit No. 62 Mataram, 83125 \\ ${ }^{*}$ korespondensi : perianggraeni212@gmail.com
}

\begin{abstract}
ABSTRAK
Derasnya arus globalisasi mengakibatkan terkikisnya kecintaan masyarakat Indonesia pada kebudayaan nusantara. Masyarakat Indonesia lebih cenderung mengkonsumsi produk impor dari pada produk lokal demi memenuhi trend fashion saat ini. Hal ini terlihat dari data Badan Pusat Statistik (BPS) yang mencatat pertumbuhan total impor barang konsumsi sepanjang Agustus 2017 sebesar USD 1,19 milyar atau naik 9,39\% dibandingkan bulan sebelumnya, sedangkan selama januari sampai Agustus 2017 tercatat sebesar USD9,07 miliar atau naik $11,76 \%$ dibandingkan Januari sampai Agustus. Kegiatan pengabdian ini bertujuan untuk menciptakan sebuah produk inovasi bernuansa nusantara yang diharapkan dapat bersaing dengan produk import. Produk yang kami hasilkan dalam kegiatan ini diberi nama "jones. Jones merupakan jam tangan yang dikombinasi dengan sentuhan kain tenun khas suku Sasak, Samawa dan Mbojo. Produk yang dihasilkan dibagi menjadi tiga tipe yakni tipe premium, tipe androiddan tipe exclusive. Dalam kurun waktu 3 bulan (April-Juni) pada tahun 2018, telah terjual sebanyak 6 pasang strap jam dan 39 unit jam tangan yang terdiri dari 22 unit jam tangan tipe premium seharga Rp. 150.000,00/per unit dan jam tipe android seharga Rp. 250.000/per unit. Strategi pemasaran yang digunakan adalah dengan mengikuti bazar, pameran, online (tokopedia dan Instagram), dan langsung menjualnya kepada konsumen.
\end{abstract}

Kata kunci:etnik, jam tangan, jones, sasambo

\section{PENDAHULUAN}

Derasnya arus $\begin{array}{r}\text { globalisasi } \\ \text { kebudayaan }\end{array}$
mengakibatkan terkikisnya
dan kecintaan masyarakat Indonesia pada
budaya. Masyarakat Indonesia lebih
cenderung mengkonsumsi produk impor
dari pada produk lokal demi memenuhi
trend fashion saat ini. Hal ini dibuktikan
dengan data yang diperoleh dari Badan
Pusat Statistik (BPS) mencatat
pertumbuhan total impor barang konsumsi
sepanjang Agustus 2017 sebesar USD1,19
milyar atau naik 9,39\% dibandingkan bulan

sebelumnya, sedangkan selama Januari sampai Agustus 2017 tercatat sebesar USD 9,07 miliar atau naik $11,76 \%$ dibandingkan Januari sampai Agustus. Diperkuat dari informasi yang disampaikan oleh budayawan, sastrawan, dan ahli filsafat Indonesia Frofesor Abdul Hadi W.M (Semiono, 2014) pemimpin-pemimpin Indonesia saat ini lebih memilih dan bangga menggunakan produk impor daripada menggunakan produk lokal. Tidak heran jika hal tersebut mengakibatkan lemahnya peran generasi muda dalam melestarikan budaya daerah masing- 
masing. Sama halnya dengan para generasi muda di Nusa Tenggara Barat (NTB). Dalam kondisi keseharian, mereka kurang berminat menggunakan produk-produk lokal dan cenderung menggunakan produk impor.

Kain tenun merupakan salah satu produk kearifan lokal suku Sasak, Samawa dan Mbojo. Kain tenun di daerah ini memiliki desain dan motif khas yang mengandung nilai-nilai budaya yang tinggi, khususnya dalam segi-segi kemampuan teknis, estetis, kadar makna simbolik dan falsafah yang terdapat di dalamnya berbeda dengan daerah-daerah yang ada di Indonesia. Potensi Provinsi Nusa Tenggara Barat (NTB) tidak hanya terkenal pada kain tenunnya saja, namun masih banyak hal lain yang dapat menjadi daya tarik wisatawan lokal maupun mancanegara untuk berkunjung ke Provinsi NTB. Ini mengindikasikan bahwa Provinsi NTB memiliki potensi yang tinggi. Potensi ini memiliki ketersesuaian dengan dokumen perencanaan nasional yaitu MP3EI (Masterplan Percepatan dan Perluasan Pembangunan Ekonomi Indonesia) dengan wilayah pada koridor 5 sebagai gerbang pariwisata dan ketahanan pangan.

Dibuktikan dengan peningkatan jumlah wisatawan yang berkunjung ke Provinsi NTB. Kepala badan pusat statistik NTB Ending Tri Wahyuningsih mengatakan bahwa pada Oktober 2016, jumlah kunjungan turis asing ke NTB mencapai 9.500 orang atau naik $8,49 \%$ jika dibanding bulan sebelumnya berrjumlah 8,756 wisatawan mancanegara. Ending Tri Wahyuningsih menambahkan apabila dibandingkan dengan oktober tahun lalu, tercatat berjumlah 7,419 turis (Republika, 2016). Jumlah ini tergolong meningkat drastis hingga naik 28,05\%. Diperkuat lagi dengan data yang didapatkan dari kepala Dinas Kebudayaan dan Pariwisata (Kadisbudpar) NTB, Mohammad Fauzal mengatakan, sampai saat ini (13/9) kunjungan wisatawan telah mencapai 2,9 juta. Artinya, sampai akhir 2016, target 3 juta wisatawan optimis akan tercapai. "kalau 2016 mampu penuhi target 3 juta wisatawan, tahun 2017 yakin diangkat 3,5 juta. Sehingga tahun 2018 dipastikan bisa mendatangkan wisatawan sebanyak 4 juta orang.

Melihat permasalahan dan potensi dari banyaknya wisatawan yang datang ke Nusa Tenggara Barat kami membuat suatu inovasi baru berupa JONES (Jam Oleh-oleh Tenun Etnik Sasambo). JONES merupakan jam tangan yang dikombinasikan dengan sentuhan kain tenun khas suku Sasak, Samawa dan Mbojo. Inovasi ini memiliki banyak keunggulan secara budaya, latar jam didesain menggunakan ikon SASAMBO dan bunyi khas suku SASAMBO seperti gendang beleq atau suara adzan yang bukan hanya sebagai pengingat waktu sholat, namun juga dapat mengingatkan pemakai pernah berinteraksi dengan budaya NTB, sehingga ikut melestarikan budaya. Hal tersebut bersesuaian dengan kenyataan bahwa trend industri pariwisata abad XXI adalah cultural tourism (Butler,1997; Fletcher, 1997) tenun diyakini mampu mengambil peran didalamnya. Inovasi JONES ini memiliki keuntungan dari segi ekonomi yaitu mampu membantu penyerapan tenaga kerja yang akhirnya berdampak pada peningkatan kesejahteraan masyarakat. Segala kelebihan yang ditawarkan melalui program pariwisata Pemerintah Nusa Tenggara Barat (NTB) diprediksi dapat membawa revolusi besar dalam internasionalisasi kearifan lokal Indonesia.

\section{METODE KEGIATAN}

\section{Gambaran Usaha}

Bisnis JONES (Jam Oleh-oleh Kain Tenun Etnik SASAMBO) dengan pemanfaatan kain tenun sasambo adalah 
industri kreatif yang mengedepankan kearifan lokal provinsi NTB. Seperti kearifan lokal dari suku SASAMBO salah satunya adalah kain tenun. Disamping itu kami juga mendesain latar jam tangan dengan menambahkan ikon yang melambangkan identitas dari Suku SASAMBO. Konsep baru yang kami tawarkan dapat digunakan dalam berbagai acara baik formal maupun informal serta digemari oleh berbagai kalangan usia khususnya generasi muda.

Produk yang dihasilkan dibagi menjadi tiga tipe yakni tipe I premium, tipe 2 android dan tipe 3 exclusive. Ketiga tipe jam tersebut dimodifikasikan menggunakan kain tenun Suku SASAMBO dengan penambahan latar belakang ikon jam yang melambangkan identitas suku SASAMBO seperti Masjid Islamic center, Peresean, Gendang Belek, rumah lengge dan istana dalam loka. Selain itu pada pengemasan JONES (Jam Oleh-Oleh Tenun Etnik SASAMBO) akan dilengkapi dengan lembaran produk knowledge dalam dua bahasa yaitu bahasa Indonesia dan Inggris untuk memperkenalkan unsur budaya yang terkandung dalam produk tersebut. Pada produk knowledge juga akan disampaikan makna dari pemakaian simbol-simbol ikon dalam produk JONES.

Kegiatan produksi jam tangan JONES dimulai dari bulan April 2018, namun aktif pada bulan Mei 2018 dan masih berlangsung sampai saat ini. Tempat usaha berlangsung di Dusun Enjak Desa Bagik Polak Kecamatan Labuapi RT. 02. Adapun rancangan produksi jam JONES yang dilakukan selama 3 bulan yaitu modal awal pembuatan jam tangan dalam satu kali produksi atau dalam satu hari yakni Rp 390.000 menghasilkan 5 unit jam tangan.

\section{Perhitungan laba atau rugi}

Dalam seminggu memproduksi jam tangan selama 4 hari yakni hari senin, selasa, rabu dan hari sabtu, dalam satu hari kami memproduksi 5 unit jam tangan dan memasarkan jam tangan 1 kali dalam seminggu sebanyak 20 unit jam tangan, sehingga selama 8 minggu kami memasarkan jam tangan sebanyak 8 kali dengan jumlah 160 unit jam tangan.

Keuntungan yang didapatkan selama 8 minggu yakni Rp 11.520.000. Pengembangan usaha melalui alternatif kerajinan industri kreatif mudah untuk dikerjakan oleh semua kalangan berbekal ketekunan, berlatih dan berbisnis, sehingga kemauan dalam menjalankan usaha kreatif ini dapat menjadi modal dasar keberlanjutan JONES. Selain itu melirik banyaknya jumlah pengrajin di Lombok, Sumbawa dan Mbojo dapat menjadi pendukung utama tersedianya bahan dasar dari produksi ini. Kain tenun dijadikan sebagai daya tarik utama dalam produk JONES (Jam Oleh-oleh Etnik SASAMBO) karena memiliki nilai etnik dan estetika. Dipandang dari nilai etnik JONES menggunakan kombinasi kain tenun pada gelang jam dan latar mesin dengan ikon yang melambangkan identitas Suku SASAMBO (Sasak, Samawa dan Mbojo) merupakan produk yang mengangkat kearifan lokal. Sehingga pemasarannya dapat membawa misi pelestarian budaya karena keindahannya pula kain tenun ini banyak diminati oleh masyarakat nasional maupun internasional. Inovasi JONES dari bentuk aksesoris, bahan dasar jam akan terus kami kembangkan. Selain itu kami akan melakukan kerja sama dengan pelaku bisnis melalui komunitas crafter agar ide dan ekspansi pemasaran JONES dapat semakin berkembang.

\section{Metode Pembuatan Jam Tangan JONES}

Produk inovasi yang diciptakan adalah JONES (Jam Oleh-Oleh Tenun Etnik Sasambo). Perpaduan mesin jam dan strap yang menggunakan ikon pada background dan instrumen musik tradisional yang mencerminkan identitas suku SASAMBO. 
1. Pembelian kerangka jam

Jam yang akan digunakan pada produk JONES pada awalnya akan dirangkai sendiri dengan melakukan pembelian komponen-komponen jam tangan. Namun karena kurangnya ketersediaan bahan baku atau komponen-komponen jam tangan khususnya di provinsi NTB dan sulitnya mecari pengrajin jam yang dapat membuat jam tangan dari awal, dipilih alternatif membeli langsung jam tangan yang sudah jadi.

2. Pengukuran dan pemotongan kain tenun Pengukuran kain disesuaikan dengan ukuran strap jam yang diinginkan. Pemotongan kain dilakukan setelah pengukuran, kain tenun dipotong sesuai dengan ukuran yang telah ditentukan.

3. Penjahitan strap jam

Kain tenun yang telah dipotong kemudiandisatukan dengan strap jam dengan cara menjahit setiap sisinya.

4. Pemasangan ikon jam

Jam yang sudah dijahit kemudian dilakukan pemasangan ikon pada background jam. Ikon jam disesuikan dengan kain tenun yang digunakan.

5. Quality control

Pengontrolan dilakukan dengan cara membersihkan benang sisa jahitan. Dan mengemas jam tangan dengan memasukkannya ke dalam kotak jam yang sudah tersedia.

6. Pemasaran

Pemasaran dilakukan secara langsung dari mulut ke mulut, secara tidak langsung seperti pamflet dan banner, dan melalui teknologi informasi seperti instagram, tokopedia dan grup whatsapp. Sehingga pembelian jam JONES dapat dilakukan secara langsung maupun online. Untuk sistem online mekanisme pembayaran bisa dilakukan dengan cara transfer melalui rekening dan paling lambat jam JONES akan sampai ke tangan konsumen dalam waktu tujuh hari.
Pada bulan Ramadhan kami mengadakan promosi dengan mengadakan give away yaitu pembagian jam tangan secara gratis bagi dua orang pemenang dan memberikan diskon 20\% dalam pembelian 1 jam tangan JONES. Khusus pada pembeli yang ining menjual kembali jam JONES (Reseller) diberikan harga yang lebih murah dari harga yang ditetapkan di pasaran.

\section{HASIL DAN PEMBAHASAN}

Selama ini, target luaran yang telah tercapai yaitu dari setiap strategi pemasaran yang dilakukan telah memperoleh peminat untuk membeli produk, dan memastikan kepuasan dari pelanggan terhadap produk yang dijual. Kemudian telah tercipta sebuah alternatif usaha baru yang mampu menghasilkan keuntungan dalam bidang penyediaan barang berupa, jam tangan modifikasi kain tenun SASAMBO.

Usaha ini juga telah dikenal oleh masyarakat secara umum diseputaran kota Mataram dan menjadi usaha yang berjalan berkesinambungan. Dalam perkembanganya usaha jam tangan JONES juga menerima pesanan sesuai dengan pesanan dari pembeli. Cukup dengan memesan gambar ikon yang diinginkan dan jenis kain tenun yang diinginkan maka pemesan (calon pembeli) akan memperoleh jam tangan sesuai dengan keinginannya.

Berikut ini disajikan Tabel 1 realisasi biaya dalam usaha jam JONES, dimana biaya ini diperlukan untuk mengerjakan jam tangan sebanyak 73 unit atau dikenal dengan 1 kali siklus

Tabel 1. Biaya Tetap/Investasi

\begin{tabular}{clccc}
\hline No & \multicolumn{1}{c}{ Item } & Jumlah & $\begin{array}{c}\text { Satuan } \\
(\mathrm{Rp})\end{array}$ & Total (Rp) \\
\hline 1 & $\begin{array}{l}\text { Alat } \\
\text { pembolong } \\
\text { jam }\end{array}$ & 1 & 190.000 & 190.000 \\
\hline Total investasi & & & 190.000 \\
\hline
\end{tabular}


Tabel 2. Biaya produksi/siklus

\begin{tabular}{|c|c|c|c|c|}
\hline No & Item & Jumlah & Satuan (Rp) & Total (Rp) \\
\hline 1 & Jam tangan & 70 & 35.000 & 2.450 .000 \\
\hline 2 & $\begin{array}{l}\text { Jam tangan } \\
\text { android }\end{array}$ & 1 & 125.000 & 125.000 \\
\hline 3 & $\begin{array}{l}\text { Jam tangan } \\
\text { water } \\
\text { resistance }\end{array}$ & 2 & 175.000 & 350.000 \\
\hline 4 & Kain bima & 1 & 515.000 & 515.000 \\
\hline 5 & $\begin{array}{l}\text { Lem } \\
\text { rajawali }\end{array}$ & 4 & 20.000 & 80.000 \\
\hline 6 & $\begin{array}{l}\text { Lem castol } \\
\text { mini }\end{array}$ & 1 & 5.000 & 5.000 \\
\hline 7 & $\begin{array}{l}\text { Lem castol } \\
\text { sedang }\end{array}$ & 2 & 7.000 & 14.000 \\
\hline 8 & $\begin{array}{l}\text { Lem } \\
\text { rajawali } \\
500 \mathrm{ml}\end{array}$ & 1 & 29.000 & 29.000 \\
\hline 9 & Jasa jahit & 79 & 10.000 & 790.000 \\
\hline 10 & $\begin{array}{l}\text { Selendang } \\
\text { tenun sasak }\end{array}$ & 6 & 65.000 & 390.000 \\
\hline 11 & Kotak jam & 4 & 110.000 & 440.000 \\
\hline 12 & $\begin{array}{l}\text { Print } \\
\text { sticker } \\
\text { icon }\end{array}$ & 9 & 6.500 & 58.000 \\
\hline 13 & $\begin{array}{l}\text { Pasang } \\
\text { icon di } \\
\text { ampenan }\end{array}$ & 25 & 5.000 & 125.000 \\
\hline 14 & $\begin{array}{l}\text { Pasang } \\
\text { icon di } \\
\text { alexander }\end{array}$ & 48 & 7.000 & 336.000 \\
\hline 15 & Kresek & 1 & 27.000 & 27.000 \\
\hline 16 & $\begin{array}{l}\text { Biaya } \\
\text { transportasi }\end{array}$ & 10 & 8.000 & 80.000 \\
\hline 17 & Kuota & 4,5 GB & 28.000 & 28.000 \\
\hline \multicolumn{4}{|c|}{ Total investasi } & 5.842 .000 \\
\hline
\end{tabular}

Tabel 3. Biaya Operasional/siklus

\begin{tabular}{|c|c|c|c|c|}
\hline No & Item & Jumlah & Satuan (Rp) & Total (Rp) \\
\hline 1 & $\begin{array}{l}\text { Buku } \\
\text { double folio }\end{array}$ & 3 & 17.000 & 51.000 \\
\hline 2 & $\begin{array}{l}\text { Print } \\
\text { panduan } \\
\text { pkm warna }\end{array}$ & 6 & 1.000 & 6.000 \\
\hline 3 & $\begin{array}{l}\text { Print } \\
\text { panduan } \\
\text { hitam putih }\end{array}$ & 14 & 4.00 & 5.500 \\
\hline 4 & $\begin{array}{l}\text { Fotocopy } \\
\text { panduan }\end{array}$ & 4 & 1.000 & 4.000 \\
\hline 5 & $\begin{array}{l}\text { Transportasi } \\
\text { pergi (grab) }\end{array}$ & 1 & 51.000 & 51.000 \\
\hline 6 & Transportasi & 1 & 53.000 & 53.000 \\
\hline 7 & Mp3 & 2 & 17.000 & 34.000 \\
\hline 8 & $\begin{array}{l}\text { Jasa } \\
\text { pembolong } \\
\text { jam }\end{array}$ & 7 & 5000 & 35.000 \\
\hline 9 & $\begin{array}{l}\text { Cangkang } \\
\text { jam }\end{array}$ & 10 & 5.000 & 50.000 \\
\hline 10 & Plastik klip & 1 & 3.000 & 3.000 \\
\hline 11 & $\begin{array}{l}\text { Print } \\
\text { famplet }\end{array}$ & 16 & 4.500 & 68.000 \\
\hline 12 & Biaya parkir & 11 & 1.000 & 11.000 \\
\hline 13 & Pengemasan & 1 & 5.500 & 5.500 \\
\hline
\end{tabular}

\begin{tabular}{|c|c|c|c|c|}
\hline 14 & $\begin{array}{l}\text { Ongkir give } \\
\text { away (JNE) }\end{array}$ & 1 & 56.000 & 56.000 \\
\hline 15 & $\begin{array}{l}\text { Print } \\
\text { proposal }\end{array}$ & 2 & 7.500 & 15.000 \\
\hline 16 & Album foto & 1 & 35.000 & 35.000 \\
\hline 17 & $\begin{array}{l}\text { Isi lem } \\
\text { tembak } \\
\text { kecil }\end{array}$ & 1 & 1.500 & 1.500 \\
\hline 18 & Talitas $2 \mathrm{~cm}$ & 1 & 1.500 & 1.500 \\
\hline 19 & Servis jam & 4 & 5.000 & 20.000 \\
\hline 20 & Baterai jam & 6 & 15.000 & 60.000 \\
\hline 21 & $\begin{array}{l}\text { Buku kiki } \\
\text { tebal }\end{array}$ & 1 & 23.500 & 23.500 \\
\hline 22 & $\begin{array}{l}\text { Print foto } \\
\text { logbook }\end{array}$ & 28 & 42.000 & 42.000 \\
\hline 23 & Kertas hvs & 80 & 125 & 10.000 \\
\hline 24 & Sterofoam & 1 & 9.800 & 9.800 \\
\hline \multicolumn{4}{|c|}{ Total investasi } & 651.300 \\
\hline
\end{tabular}

Dalam kurun waktu 3 bulan (April-Juni) 2018: telah terjual sebanyak 6 pasang strap jam dan 51 unit jam tangan, yang terdiri dari: 50 unit jam tipe 1premiumseharga 150.000,00 perunit dan jam tipe 2 android seharga 250.000,00 perunit. Pada bulan Ramadhan kami mengadakan promosi dengan mengadakan give away serta memberikan diskon sebesar 20\% dalam pembelian 1 unit jam dan bagi pembeli yang ingin menjual kembali jam JONES (Reseller) diberikan harga yang lebih murah dari harga yang ditetapkan di pasaran. Rincian total penjualan dijelaskan dalam Tabel 4

Tabel 4. Total penjualan selama 3 bulan (April-Juni 2018)

\begin{tabular}{|c|c|c|c|c|}
\hline No & Nama Produk & Jumlah & Satuan (Rp) & Total (Rp) \\
\hline 1 & $\begin{array}{l}\text { Jam tipe } 1 \\
\text { (Launching } \\
\text { perdana) }\end{array}$ & 3 & 120.000 & 360.000 \\
\hline 2 & Jam tipe 1 & 30 & 150.000 & 4.500 .000 \\
\hline 3 & $\begin{array}{l}\text { Jam tipe } 2 \\
\text { (Android) }\end{array}$ & 1 & 250.000 & 250.000 \\
\hline 4 & $\begin{array}{l}\text { Jam tipe } 1 \\
\text { (promo } \\
\text { ramadhan) }\end{array}$ & 10 & 120.000 & 1.200 .000 \\
\hline 5 & $\begin{array}{l}\text { Jam tipe } 1 \\
\text { (reseller) }\end{array}$ & 7 & 100.000 & 700.000 \\
\hline 6 & Strap jam & 6 & 50.0000 & 300.000 \\
\hline \multicolumn{4}{|c|}{ Total Penjualan } & 7.310 .000 \\
\hline
\end{tabular}


Total pemasukannya adalah Rp. 7.310.000, sedangkan total biaya untuk produksi satu unit jam tipe 1 adalah $\mathrm{Rp}$ 70.000, tipe 2 (android) adalah Rp 161.500 dan strap jam Rp 17.000.

Tabel 5. Biaya Produksi Per Unit Jam

\begin{tabular}{clr}
\hline No & Nama Produk & \multicolumn{2}{c}{ Satuan (Rp) } \\
\hline 1 & Jam tangan & 35.000 \\
2 & Kain tenun & 5.000 \\
3 & Kotak & 10.000 \\
4 & Sticker & 500 \\
5 & Biaya pasang sticker & 7.000 \\
6 & Jasa jahit & 10.000 \\
7 & Produk knowledge & 1.000 \\
8 & Lem & 1.500 \\
\hline Total Produksi & 70.000 \\
\hline
\end{tabular}

Tabel 6. Laba-Rugi

\begin{tabular}{lr}
\hline Keterangan & 51 Jam+6 Strap) \\
\hline Penjualan/Pendapatan & 7.310 .000 \\
Biaya produksi jam & 3.570 .000 \\
Biaya produksi strap & 120.000 \\
\hline Total biaya produksi & 3.690 .000 \\
Laba (rugi) bersih & 3.620 .000 \\
\hline
\end{tabular}

Dari penjualan 57 jam JONES sudah dikatakan dapat memperoleh keuntungan sebesar Rp 3.620.000

Tabel 7. Rencana penjualan ke depan

\begin{tabular}{clrrr}
\hline No & Nama Produk & Jumlah & Satuan (Rp) & Total (Rp) \\
\hline 1 & Jam tangan tipe 1 & 57 & 150.000 & 8.550 .000 \\
2 & Jam tangan tipe 2 & 10 & 250.000 & 2.500 .000 \\
3 & Jam tangan tipe 3 & 20 & 250.000 & 5.000 .000 \\
\hline & & & & 16.050 .000 \\
\hline
\end{tabular}

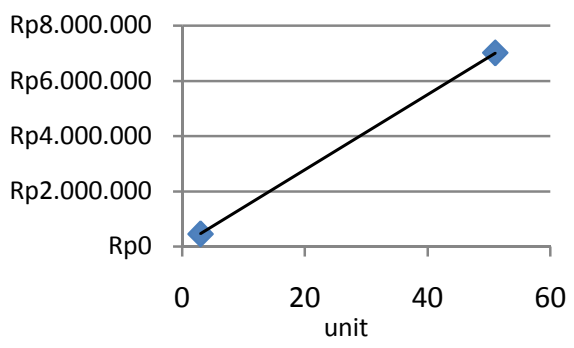

Gambar1. Grafik BEP (Break Event Point)
Untuk mencapai BEP (Break Even Point) jam JONES atau dimana suatu usaha jam JONES dikatakan tidak untung dan tidak rugi atau yang lebih dikenal dengan biaya balik modal, maka jam JONES harus dijual sebesar 3 unit jam dengan total harga sebesar Rp 462.000. Adapun jam JONES dalam kurun waktu 3 bulan terjual sebanyak 51 unit jam dengan total harga sebesar Rp 7.010.000. Hal ini menunjukkan bahwa usaha jam JONES sudah melebihi BEP.

\section{KESIMPULAN DAN SARAN}

JONES merupakan jam tangan yang dikombinasikan dengan sentuhan kain tenun khas suku Sasak, Samawa dan Mbojo. Produk jam JONES sudah banyak mendapatkan respon positif dari berbagai pelanggan di beberapa kalangan masyarakat di Kota Mataram. Dalam perkembanganya usaha jam tangan JONES juga menerima pesanan sesuai permintaan dari pembeli. Konsumen dapat memesan gambar ikon yang diinginkan dan jenis kain tenun yang diinginkan maka pemesan (calon pembeli) akan memperoleh jam tangan sesuai dengan keinginannya. Jumlah produk yang terjual dalam kurun waktu 3 bulan berjumlah 51 unit jam dan 6 pasang strap dengan total pemasukan sebesar $\mathrm{Rp}$ 7.310.000 dan keuntungan sebesar $\mathrm{Rp}$ 3.620.000 sehingga penjualan jam JONES sudah melebihi BEP, yang artinya usaha jam JONES layak untuk bersaing di pasaran.

\section{DAFTAR PUSTAKA}

Fletcher, J. 1997. Heritage Tourism: Enhancing the Net Benefits of Tourism.

Dalam Wiendu Nuryati (ed.), Tourism and Heritage Management. Yogyakarta: Gadjah Mada University Press, pp 1424. 